\title{
Principal's Strategy in Developing Al-Qur'an Learning in Madrasah Tsanawiyah
}

\author{
Mukhammad Yusuf Ro'is ${ }^{1}$, Mauhibur Rokhman ${ }^{2}$, \\ ${ }^{1}$ Institut Pesantren KH. Abdul Chalim Pacet Mojokerto, Indonesia \\ ${ }^{2}$ Institut Pesantren KH. Abdul Chalim Pacet Mojokerto, Indonesia \\ e-mail: yusufrois@gmail.com, fadlypwk@ub.ac.id
}

Submitted: 09-08-2021 Revised : 22-09-2021 Accepted: 29-10-2021

\begin{abstract}
The purpose of this article is to explain and analyze the Qur'anic learning process and the principal's strategy in developing Qur'anic learning at MTs Sunan Giri in Probolinggo. This article uses a qualitative research type with a case study approach. The research site is at MTs Sunan Giri Probolinggo. The information for this research is the principal of the madrasa, the deputy head of the madrasa, the teacher concerned and the students. This research was conducted from January to May 2021. The results of this article are: 1) The process of learning the Koran is carried out in learning and extracurricular activities. 2) the strategies carried out by the principal are: The strategy of the principal of MTs Sunan Giri Probolinggo City in developing Al-Qur'an learning in his school there are several roles, namely: 1) the principal acts as an educator (educator), 2) the principal acts as a manager , 3) the principal acts as an administrator, 4) the principal acts as a supervisor, 4) the principal acts as a leader, 5) the principal acts as an innovator, 6 ) the principal acts as an motivator, 6) the principal acts as an innovator and facilitator.
\end{abstract}

Keywords: Learning Strategy, Head of Madrasah, Al-Qur'an Learning.

\begin{abstract}
ABSTRAK. Tujuan artikel ini adalah untuk menjelaskan dan menganalisis proses pembelajaran AL-Qur-an dan strategi kepala sekolah dalam mengembangkan pembelajaran Al-Qur’an di MTs Sunan Giri di Probolinggo. Artike ini menggunakan jenis penelitian kualitatif dengan pendekatan sudi kasus. Tempat penelitian di MTs Sunan Giri Probolinggo. Infroma penelitian ini adalah kepala madrasah, wakil kepala madrasah, guru yang bersangkutan dan peserta didik. penelitian ini dilakukan selama January hingga Mei 2021. Hasil artikel ini adalah: 1) Proses pembelajaran AlQuran dilakukan dalam pembelajaran dan kegiatan ekstrakulikuler. 2) strategi yang dilakukan kepala sekolah adalah: Strategi kepala MTs Sunan Giri Kota Probolinggo dalam memgembangkan pembelajaran Al-Qur'an di sekolahnya terdapat beberapa peran, yaitu: 1) kepala sekolah berperan sebagai edukator (pendidik), 2) kepala sekolah berperan sebagai manajer, 3) kepala sekolah berperan sebagai administrator, 4) kepala sekolah berperan sebagai supervisor, 4) kepala isekolah iberperan sebagai leader (pemimpin), 5) kepala sekolah berperan sebagai innovator, 6) kepala isekolah berperan sebagai motivator, 6) kepala isekolah berperan sebagai fasilitator.
\end{abstract}

Kata Kunci: Strategi Pembelajaran, Kepala Madrasah, Pembelajaran Al-Qur an.

https://doi.org/10.31538/munaddhomah.v2i2.77

How to Cite Rois, MY, Usman, F. (2021). Strategi Kepala Sekolah Dalam Mengembangkan Pembelajaran Al-Qu'ran di Madrasah Tsanawiyah. Munaddhomah: Jurnal Manajemen Pendidikan Islam, Volume (2), 103-115

\section{INTRODUCTION}

Education as one of the needs that can not be separated from life and human life. What is meant by needs is a social function, enlightenment, guidance, a means of growth that prepares and opens up and forms life discipline (Muslimin \& Kartiko, 2020). This brings the understanding that 
no matter how simple a human community is, it still needs education. In a general sense, the life of the community will be determined by the extent of educational activities in it. Because education is naturally a necessity of human life (M. A. Abdullah, 2017; Agung, 2018).

Education is an effort to improve oneself in all its aspects, including activities that involve teachers and those that do not involve teachers (educators), including formal and informal education, aspects that are fostered by education are all aspects of personality, so that the desired characters are formed. With education, it is expected to produce quality and responsible human beings and be able to anticipate the future (Tafsir, 2012).

Islamic religious education is a conscious and planned effort in preparing students to recognize, understand, live up to faith, fear, and have noble character in practicing the teachings of Islam from the main source of the holy book Al Qur'an and hadith, through guidance, teaching, training activities. , and the use of experience (L. Abdullah, 2018; Abdurrahman, 2016; Amri et al., 2019). Accompanied by demands to respect adherents of other religions in society until the realization of national unity and integrity.

It is proper for educators or teachers to reflect on themselves and listen to various criticisms submitted to Islamic religious education (IRE) teachers. As stated by Mochtar Buchori in (Muhaimin, 2012)that religious education still fails because its educational practice only pays attention to cognitive aspects and ignores affective aspects and as a result there is a gap between religious knowledge and practice. So it is not able to form moral individuals, even though the core of religious education is moral education.

Seeing the phenomena above will be a challenge for Islamic religious education in schools. As stated in the standard of competence and basic competence at the MTs/SMP level that religious education is intended to increase spiritual potential and shape students to become human beings who believe and fear God Almighty and have noble character (Baharun \& Ummah, 2018; Berkowitz \& Bier, 2016). One of the factors that play an important role in the development of religious culture is the active role of the school community of teachers, employees, students and school principals. However, as school leaders, school principals have a fairly large share and role because in the hands of the principal these policies are made and then implemented by all school members (Ilmi et al., 2021; Sobri, 2019).

Liphan James H., et.al in (Wahjosumidjo, 1999) said that the principal's success study shows that the principal is someone who determines the center point and rhythm of a school. Even further, the study concluded that "school success is the success of the principal". Some of the principals are described as people who have high expectations for staff and students, principals are those who know a lot about their duties and those who set the rhythm for their school (Asmendri, 2014; Brooks \& Sungtong, 2016; Fitriani \& Hakim, 2021).

The principal as the person responsible for the implementation of education and teaching in educational institutions, must have the readiness and ability to generate personal morale (Ariyanti et al., 2019; Brooks \& Mutohar, 2018; Nurulloh et al., 2020). A leader must also be able to create a climate and atmosphere that is conducive, safe, comfortable, peaceful, fun, and full of enthusiasm in working for workers and students (Fitriani, 2017). So that the implementation of teaching and learning activities can run orderly and smoothly in achieving the expected goals. For this reason, every school principal should have a strong leadership role in the sense of being able 
to influence, guide, coordinate, and mobilize others who have to do with the development of education and teaching so that the activities carried out can be more effective and efficient in achieving educational and teaching goals (Fatoni, 2017; Fauzi, 2017).

Al-Qur'an reading activities are also included in extracurricular activities, which are specifically for students who have special abilities, talents and interests. The activity is in the form of the art of reading the Qur'an (recitations and tartils of the Qur'an) (Kosim et al., 2019; Prayoga et al., 2019). In addition to the above, the religious culture at MTs Sunan Giri, Probolinggo City, which researchers have currently observed is that school residents always reflect Islamic values. This can be seen from all school residents whose female teachers, administrative staff, and students always wear Muslim clothes (bijab). Activities that describe the religious culture run continuously and in addition there are many other temporal religious activities, such as the fast Ramadan Islamic boarding school, commemoration of Islamic holidays, Al-Qur'an reading competition (MTQ between classes), and Islamic art.

Therefore, the role of educational institutions as cultivators of noble religious and national values needs to protect and seek more effective methods for the success of religious education in this country. One of the schools that has developed it is MTs Sunan Giri Probolinggo City, the school is able to develop religious learning well in its school environment, making it a tradition to read the Qur'an for 7-10 minutes before the first hour starts. Besides that, reading activities of the Qur'an in the form of joint yasinan are carried out every Friday in the first hour and are attended by all students, teachers and employees.

The religious learning described at MTs Sunan Giri Probolinggo City can run and become entrenched in the school environment. It is the idea of a school principal who is fully supported by teachers, students and all school members. The principal's idea was conveyed to the religious education teachers and they responded by organizing and programming the religious activities on a scheduled basis. But religious education teachers feel the need to involve teachers from other fields of study to form a kind of joint commitment to facilitate the development of a culture of reading the Qur'an in schools.

The researchers observed that the principal of MTs Sunan Giri Probolinggo City had high intellectual abilities, emotional maturity and religious awareness. Besides that, the principal of MTs Sunan Giri Probolinggo City is also an ustadz, preacher, and also the Chairperson of the Probolingg city level TPQ management so that the school principal is an example who is able to mobilize and encourage school residents to have religious awareness that is cultured in the school environment. One of the activities is to develop Qur'anic learning for students at MTs Sunan Giri Probolinggo City.

\section{METHOD}

This article uses qualitative research with a case study approach. The reason for using a case study is that the place being researched has problems related to how the principal's strategy in applying student discipline to memorizing the Qur'an is. Learning the Qur'an needs to be developed because it is the identity of the institution. The place of this research is at MTs Sunan Giri, Probolinggo City, which is located in Sukapura No. 127, Triwung Kidul Village, Kademangan District, Probolinggo City. The implementation of this research was carried out from January to May 2021. The informants of this research were the head of the Madrasah, the 
IMtaq supervisor, the deputy head of the madrasa and several teachers. Data collection techniques with observation, interviews and documentation. The data collection technique is an effort to observe the variables carefully through the methods of observation, interviews and documentation. Data analysis techniques follow the model (Creswell, 2012; Lexy J, 2011; Miles et al., 2014) namely by 1) data reduction, 2) data presentation and, 3) verification and drawing conclusions.

\section{RESULTS AND DISCUSSION}

Based on the data exposure on the sub-focus of learning the Qur'an at MTs Sunan Giri Probolinggo City, the researcher can put forward some research findings as follows:

\section{Learning the Qur'an at MTs Sunan Giri Probolinggo City}

In general, the forms of Al-Qur'an Learning developed at MTs Sunan Giri Probolinggo City include: 1) IMTAQ activities which are held every Friday consisting of: Faith Friday (religious and yasinan lectures), Clean Friday (gotong royong cleaning the school environment and the mosque in the village), Healthy Friday (a leisurely walk outside the school). 2) Ngaji Jama', which is learning to read the Qur'an properly and correctly, this activity is carried out 7-10 minutes before the first hour starts and is directly guided by the teacher who teaches in the first hour. 3) Self-development activities through extracurricular recitations and Al-Qur'an tartil activities which are carried out in the afternoon 2 times a week. In particular, the activities of developing Al-Qur'an learning at MTs Sunan Giri Probolinggo City based on the findings of the researchers are:

\section{Forms of activity}

The teaching activity to read the Qur'an which took place at MTs Sunan Giri Probolinggo City was carried out in the form of Ngaji Jama', where students were present at school at 07.00 am and went straight to their respective classes and prepared the holy book of the Qur'an and also the iqra' book for those who are not fluent in reading the Qur'an, they read together being guided and guided by the teacher who teaches in the first hour, meanwhile the researcher also observes that sometimes the principal sometimes controls these activities in their respective schools. class. The activity lasted for 7-10 minutes, until the first hour arrived at 07.15 , at 07.15 the teacher continued with their respective subjects.

Based on the notes that the researchers got in the field, the students of MTs Sunan Giri Probolinggo City often won several competitions in the religious field, as described in table 4.2. Based on the document records that the researcher describes in table 6 above, it shows that MTs Sunan Giri Probolinggo City has achievements to be proud of in the religious field, in the AlQur'an recitation branch it always gets first place at both the sub-district and student levels in the Kademangan sub-district.

\section{Teacher}

Based on the information that the researchers got from the results of in-depth interviews, participation observations and also documentation studies at MTs Sunan Giri Probolinggo City that the Al-Qur'an reading activity that was carried out had been running since the principal who is now the head of the school. The learning of the Qur'an which was developed at MTs Sunan 
Giri Probolinggo City went well and was scheduled according to the SK for the division of tasks that had been set by the Principal. The Qur'an reading activity involved all existing teachers, especially teachers who taught in the first hour directly providing teaching in their respective classes, other staff for coaching recitations and tartils as well as other religious activities were appointed from teachers who had the potential and greater ability to read the Qur'an. Because it has many potential and competent teachers, the principal does not involve and seek personnel from outside the school to assist the Al-Qur'an teaching program.

Therefore, from several archives and school documents, the researchers found a clear division of tasks regarding the implementation of the Qur'an teaching program at MTs Sunan Giri Probolinggo City. The division of tasks is determined by the school principal through the Decree. Based on the principal's decree above, it shows the seriousness of the principal and all components in the school to develop Al-Qur'an learning at MTs Sunan Giri, Probolinggo City. Although in its implementation based on the results of direct observations of researchers in the field, there are still shortcomings, namely the delay factor of teachers and students arriving on time at school

\section{Teaching Method}

Based on the findings of researchers in the field that the method used in teaching reading the Qur'an at MTs Sunan Giri Probolinggo City is the iqra' method. This method is specifically for students who cannot read and are not fluent in reading the Qur'an, although from the findings of researchers there are still teachers who do not know the application of the Iqra method, namely researchers still see teachers who teach by guiding students to imitate their teacher's reading. , even though guiding students in reading is avoided in the iqra' method. As for students who are already fluent in their reading, they do tadarus together in class guided and guided by the teacher who teaches in the first hour, besides that for students who are already fluent in reading, they are given the task of memorizing several short verses and selected verses and depositing their memorization at the end of the day. next week.

Whereas in extracurricular activities of recitations and tartil Al-Qur'an the method and system used is a mixed system between classical and private, private is a method where the teacher who teaches sings the verses of the Qur'an then the students follow and imitate the teacher's voice according to the teacher's voice. with the rhythm of the song taught together. While the private method means a method where students sing and practice verses that have been exemplified and taught by the teacher individually or one by one. Based on the findings of the researcher, the rhythm of the songs taught in the recitation lessons at MTs Sunan Giri Probolinggo City is still learning three kinds of songs, namely the bayati song, the saba' song, and the nahwan song, while the other four songs have not been taught because the three songs have not been mastered by all of the students.

\section{Implications of Implementation of Activities}

Based on the findings of researchers in the field, both based on direct observations, indepth interviews and also documentation studies, it shows that the implications of the implementation of teaching reading the Qur'an at MTs Sunan Giri Probolinggo City have brought many positive changes and influences for students, especially for students who previously cannot read the Qur'an or who have not read the Qur'an fluently. It is also seen that there are no fights between internal students and students from other schools. 
Based on some of the explanations from the students of MTs Sunan Giri Probolinggo City above, it is clear that the Qur'anic learning development activities carried out at the school have brought many positive results that are felt by the students, both in the form of reading the Qur'an. Plural recitations and extracurricular activities carried out in the afternoon in the form of recitations and tartils of the Qur'an. Many of the students at MTs Sunan Giri Probolinggo City are already able to read the Al-Qur'an properly and correctly, where previously they did not / did not know and were not fluent in reading the Qur'an, and even some of them often took part in activities- MTQ/STQ competition activities at the student level, sub-district and even Dompu district level for several competitions including: recitations, tartils, fahmil Qur'an, syarhil Qur'an, calligraphy and kasidah tambourines.

The research findings in this study also show that activities in developing Qur'anic learning at MTs Sunan Giri Probolinggo City have very noble goals, including: 1) It is hoped that with the Al-Qur'an teaching program in schools all students of the school can read the Qur'an properly and correctly, 2) It is hoped that it can be embedded in students about the importance of reading and loving the Qur'an as the holy book of Muslims, 3) Students are expected to be able to practice religious teachings in their daily lives. days as contained in the Qur'an, 4) it is hoped that the Ngaji Jama'/reading the Qur'an at MTs Sunan Giri Probolinggo City can be entrenched in the future so that it can fortify students from bad influences in the future. outside of school.

\section{Principal's Strategy in Developing Al-Qur'an Learning at MTs Sunan Giri Probolinggo City}

Not all school principals have the ability to manage and lead teachers, staff, and students in a school that is still very remote, MTs Sunan Giri Probolinggo City has developed Al-Qur'an learning in the form of Ngaji Jama' activities and extracurricular activities Tilawah Al -Qur'an. This program is the idea of a school principal who can be said besides being a formal leader in his position as a school principal, he can also be said to be a religious leader because of his strengths and abilities in the field of religion. Besides his profession as a general teacher, he also works as an ustadz, he is also a qori', and also serves as a judge on the MTQ/STQ activities in Pekat subdistrict. The superior program created at his school is considered successful and capable because he manages the activities of reading the Qur'an by increasing his role in developing Al-Qur'an learning at the school based on the vision, mission and goals of MTs Sunan Giri Probolinggo City..

Based on the findings of researchers at the research location, both direct observation and in-depth interviews and documentation studies indicate that the principal of MTs Sunan Giri Probolinggo City in developing Al-Qur'an learning in his school there are several roles, namely: a) acting as an educator (educator), b) acting as a manager, c) acting as an administrator, d) acting as a supervisor, d) acting as a leader (leader), e) acting as an innovator, f) acting as a motivator, and finally what researchers found was, g) acting as a facilitator.

\section{Role as Educator}

In carrying out his role as an educator, the head of MTs Sunan Giri Probolinggo City has the right strategy to increase the professionalism of the education staff in his school. He tries to create a conducive school climate, provides advice to all school members, provides guidance to teachers, employees and students. The principal also gave encouragement to the education staff 
in the school to carry out the activities of cultivating the reading of the Qur'an at MTs Sunan Giri Probolinggo City, these activities can run well according to the schedule and division of tasks that have been set together and these activities get high attention and enthusiasm from all school residents

Another information that the researchers found was that to add insight, principals often involve teachers in training and upgrading, especially those related to coaching or training about teaching the Qur'an or the iqra' method at school level. Meanwhile, the upgrading or training at the district level related to the method of teaching the Qur'an which was held by the Office of the Ministry of Religion of Dompu Regency and held by LPPTKA-BKPRMI of Dompu Regency had never been followed by teachers at MTs Sunan Giri Probolinggo City.

The principal always pays attention to and participates in controlling the activities of reading the Qur'an in each class, he always reminds the students to pay attention to the effective use of learning time to read the Qur'an in class, because reading the Qur'an is carried out at 7-10 minutes before the first hour starts, he always reminds the teachers to start and end the learning to read the Qur'an according to the specified time and use that time effectively and efficiently, not to disturb and take time/delay until it exceeds the time for the first lesson.

Based on the information above, the principal of MTs Sunan Giri City Probolinggo showed his role in developing the culture of reading the Qur'an at the school, namely acting as an educator or educator. In carrying out his role as the head educator of MTs Sunan Giri, Probolinggo City seems to have a charismatic type of leader with a situational approach, and an instructive style.

\section{Acting as Manager}

In order to carry out its role and function as a manager, the head of MTs Sunan Giri Probolinggo City has the right strategy to empower educational staff through cooperation or cooperation, and encourage the involvement of all staff in various activities that support school programs, including the program to develop Al-Qur'an learning. 'an at school.

Based on the findings of the researchers that the principal of MTs Sunan Giri Probolinggo City is related to his role as a manager in developing Al-Qur'an learning in his school, it shows that the program to develop Al-Qur'an learning which was carried out at MTs Sunan Giri Probolinggo City was carried out through several processes, starting from planning, organizing, implementing, leading, controlling, mobilizing and utilizing existing resources, especially teachers, employees and students in order to achieve the expected goals. At the beginning of planning to hold Al-Qur'an reading activities at school when he was just appointed as principal at MTs Sunan Giri Probolinggo City, he saw that the program had not been implemented by the previous school principal and the plan received a good response from all school residents., school committees and the community, then to facilitate and organize these activities, finally through the Principal's Decree Number: 81/MTs.SG/1/2015 he determined several personnel who were taken from competent teachers and had special potential to foster these activities, Al-Qur'an teaching activities at MTs Sunan Giri Probolinggo City can run well until now as expected and planned.

As the head manager of MTs Sunan Giri Probolinggo City, he strives to continue to utilize all school resources in order to realize the vision, mission and achieve school goals in relation to 
the development of Al-Qur'an learning at MTs Sunan Giri Probolinggo City. resources in schools and continue to try to move teachers, administration and students in carrying out these activities and programs.

From some of the information and findings above, the researcher can explain that the head of MTs Sunan Giri Probolinggo City has a role as a manager in developing Al-Qur'an learning in his school, this is evidenced by the indication that the head of MTs Sunan Giri Probolinggo City in carrying out these activities through managerial process, which starts from planning, organizing, implementing, leading, controlling, and mobilizing and utilizing existing resources and personnel.

In addition, in increasing the professionalism of the education staff in schools, the principal of MTs Sunan Giri Probolinggo City continues to collaborate with education staff and other parties involved in carrying out each activity. As the head manager of MTs Sunan Giri Probolinggo City, he continues to strive to utilize all school resources in order to realize the vision, mission and achieve school goals in relation to the development of Al-Qur'an learning at MTs Sunan Giri Probolinggo City, the head of MTs Sunan Giri Probolinggo also keep and keep trying to optimize the existing resources at MTs Sunan Giri Probolinggo City and continue to try to move teachers, administration and students in carrying out their superior activities and programs, namely developing Al-Qur'an learning.

From the description above, the researcher can conclude that the type of leadership displayed by the head of MTs Sunan Giri Probolinggo City in his role as a manager is a democratic type, although some seem authoritarian but within reasonable limits according to conditions, the leadership style is delegative and the type of leadership is transactional.

\section{Acting as Administrator}

In carrying out his role as the head administrator of MTs Sunan Giri Probolinggo City, especially in developing the learning of the Qur'an, he recorded, compiled and documented the entire program of activities. Specifically, the principal included Ngaji Jama' / teaching reading the Qur'an as an activity that must be cultivated, and this activity must be followed by all students, and to manage these activities so that they can run well he appointed several teacher councils as coaches and mentors. To coordinate the course of the activity, he appointed competent teachers based on the decree for the division of tasks that the principal issued, so that the atmosphere of the activity was carried out comfortably. Iqra' books and a number of Al-Qur'an because there are still many students who do not have Iqra' and Al-Qur'an.

Based on the findings and information presented by some of the informants above, it shows that the head of MTs Sunan Giri Probolinggo City carries out his role as administrator in relation to financial management used for incentives/hohor for teaching staff and supervisors of Al-Qur'an teaching activities. In addition, the head of MTs Sunan Giri, Probolinggo City allocated special funds for the procurement of the holy book of the Qur'an and books of iqra' for the purpose of teaching reading the Qur'an. The researcher's findings in relation to the role of administrator are that in managing curriculum administration and archiving administration, it seems that it is still not managed neatly and still doesn't seem good, that is, researchers do not find archives or documents about student development during Ngaji Jama' activities. Researchers 
also did not find any proper management related to Ngaji Jama' activities, whether it was Mulok activities or extra activities that were required for all students.

\section{Acting as Supervisor}

As a supervisor, the principal of MTs Sunan Giri Probolinggo City has done many things to improve the quality of learning in schools. In relation to the development of Al-Qur'an learning in schools, based on the findings of researchers at the research site, the results of indepth interviews and direct observations showed that the principal of MTs Sunan Giri Probolinggo City carried out his role as a supervisor in the context of developing Al-Qur'an learning at MTs Sunan Giri. In the city of Probolinggo, some of what the principal as supervisor did was to conduct group discussions with all components in the school regarding the preparation of the Al-Qur'an learning development activity plan program at the school, conduct class visits to control and supervise the activities carried out by the school. teachers in each class, both in reading the Qur'an/recitation of the congregation and teaching and learning activities (KBM). In addition, the head of MTs Sunan Giri Probolinggo City carried out learning simulations and individual talks as a form of his responsibility in providing input and improvements in order to increase the insight and knowledge of the teachers about the Al-Qur'an teaching method. In carrying out his role as supervisor, the principal shows a participatory leadership style.

\section{Acting as a Leader}

As a leader (leader) the head of MTs Sunan Giri Probolinggo City is able to provide instructions and supervision, open two-way communication, and delegate tasks, based on the researcher's findings that when the head of MTs Sunan Giri Probolinggo City carries out official duties outside the school, he delegates his duties to one of the vice principals to carry out their duties and control the activities carried out at the school.

Other findings from the results of in-depth interviews and observation of the researcher's participation also found that the Head of MTs Sunan Giri Probolinggo City in carrying out his role as a leader or leader related to the development of Al-Qur'an learning at MTs Sunan Giri City Probolinggo showed that as a leader he had a special character. which includes personality, basic skills, professional experience and knowledge, administrative and supervisory knowledge, knowledge of educators, school vision and mission, communication skills with all school members, understanding the conditions and characteristics of students, he is also a principal who can receive input, suggestions and criticisms from various parties to improve their leadership, although sometimes the principal seems to be authoritarian in making a policy, but his authoritarianism is still within reasonable limits, namely in certain situations and conditions that require the principal $h$ is authoritarian, for example, when entering lessons on reading the Qur'an as mulok ngaji jama', even though there are 2 or 3 teachers who do not agree with the program, even though in the end they agree and implement the school's flagship program. However, with his power, the principal decided to include the jama' recitation program as a mulok in the school.

As a head leader of MTs Sunan Giri Probolinggo City, he is also able to encourage the emergence of a strong will with enthusiasm and confidence for the staff (teachers and employees) in carrying out their respective duties, providing guidance and direction to the staff (teachers and employees) of progress. and inspire the school in achieving its goals. In carrying out this role, the 
head of MTs Sunan Giri City Probolinggo shows a Delegative leadership style and a democratic type of leadership.

\section{Acting as an Innovator}

The researcher's findings in relation to his role and function as an innovator, the head of MTs Sunan Giri Probolinggo City has the right strategy to establish a harmonious relationship with the environment, seek new ideas, integrate every activity, set an example for all education staff in the school, and develop models for learning. innovative learning models, such as incorporating the Qur'anic learning development program in schools as a superior program that is not necessarily found in other schools..

Thus, the information above shows that the principal of MTs Sunan Giri Probolinggo City acts as an innovator by including the study of the Qur'an as a congregational prayer in his school. So in this case the head of MTs Sunan Giri Probolinggo City applies a type of visionary leadership.

\section{Act as Motivator}

As a motivator, the head of MTs Sunan Giri Probolinggo City has the right strategy to motivate teachers and employees in carrying out various tasks and functions..

Based on the researcher's findings from interviews and in-depth observations in this study related to his role as a motivator in developing Al-Qur'an learning at MTs Sunan Giri Probolinggo City, it shows that the principal always motivates all teachers and employees as well as students to help implement The school's flagship program in the field of religion is the program to develop the learning of the Qur'an which is still running smoothly. Because by providing motivation to all school members, they will be able to move other factors towards work effectiveness, even motivation is often equated with machines and cars that function as drivers and influence. Therefore, in this case the principal applies a reward system to teachers, especially teachers who guide Al-Qur'an teaching activities by giving gifts or increasing incentives and meeting their needs.

The last finding of the researcher in relation to the leadership role of the principal in developing Al-Qur'an learning at MTs Sunan Giri Probolinggo City is to act as a facilitator. The role of the principal as a facilitator is not adopted by the researcher in a special sub-discussion because the role as a facilitator is the same as or part of the role as an educator. As a facilitator and educator in developing the learning of the Qur'an in schools, the principal of MTs Sunan Giri Probolinggo City is often a tutor and direct resource person in providing teaching materials or teaching methods of the Qur'an at the school level.

Temuan lainnya menunjukkan bahwa kepala MTs Sunan Giri Kota Probolinggo juga menjadi fasilitator dan pendidik untuk mengajar tilawah Al-Qur'an pada kegiatan ekstrakurikuler yang dilaksanakan pada sore hari.Dari berbagai temuan di atas menunjukkan bahwa kepala MTs Sunan Giri Kota Probolinggo telah menjalankan berbagai peran dalam mengembangkan pembelajan Al-Qur'an di sekolahnya. Dengan dilaksanakannya berbagai peran tersebut oleh kepala sekolah sehingga pelaksanaan kegiatan pengembangan pembelajan Al-Qur'an dapat terlaksana sesuai dengan jadwal dan SK pembagian tugas pembinaan baca Qur'an di MTs Sunan Giri Kota Probolinggo. 


\section{CONCLUSSION}

Al-Qur'an learning that took place at MTs Sunan Giri Probolinggo City was carried out in the form of Ngaji Jama', also in the form of extracurricular activities held in the afternoon, the activities were in the form of recitation and tartil lessons (the art of reading the Qur'an). The teaching staff comes from teachers in the school, especially teachers who teach in the first hour. The method used in teaching reading the Qur'an at MTs Sunan Giri Probolinggo City is the iqra 'and tadarus together method. While in extracurricular activities of recitation and tartil Al-Qur'an the method and system used is a mixed system between classical and private. The implications of the implementation of teaching activities to read the Qur'an at MTs Sunan Giri Probolinggo City have brought many positive changes and influences for students, especially for students who previously could not read the Qur'an or who have not been fluent in reading the Qur'an., with the implementation of the teaching of the Qur'an, the students are able to read the Qur'an properly and correctly. Al-Qur'an learning at MTs Sunan Giri City Probolinggo went well and smoothly although there were still shortcomings, but these activities could involve all school members, especially teachers and students so that they could provide quite proud results for the school. By developing the learning of the Qur'an, the culture will automatically bring benefits so that students can read the Qur'an properly and correctly, love the Qur'an as the holy book, and can practice Islamic teachings in their daily lives. day and to protect and fortify the school community, especially students, from the negative influences of the environment outside the school.

The strategy of the principal of MTs Sunan Giri Probolinggo City in developing Al-Qur'an learning in his school there are several roles, namely: 1) the principal acts as an educator (educator), 2) the principal acts as a manager, 3) the principal acts as an administrator, 4) the principal acts as a supervisor, 4) the principal acts as a leader, 5) the principal acts as an innovator, 6) the principal acts as an immotivator, 6) the principal acts as a facilitator. Thus the principal of the school acts as a central force that is the driving force of school life so that the implementation of Al-Qur'an learning development activities can be carried out well at MTs Sunan Giri, Probolinggo City, although there are still various shortcomings, but these shortcomings can be used as a whip to further improve the quality of education. even better direction. In carrying out these roles, the head of MTs Sunan Giri Probolinggo City seems to show various leadership styles according to the conditions he plays. The type of leadership is charismatic type, democratic type, and sometimes has an autocratic leadership type within reasonable limits according to conditions and circumstances.

\section{REFERENCES}

Abdullah, L. (2018). Kontribusi Tarekat Naqsabandiyah Terhadap Pendidikan Agama Islam Dan Perubahan Perilaku Sosial Jamaah. Nazhruna, 1(1), 1-13. http://ejournal.ikhac.ac.id/index.php/NAZHRUNA/article/view/82

Abdullah, M. A. (2017). Islamic Studies in Higher Education in Indonesia: Challenges, Impact and Prospects for the World Community. Al-Jami'ab: Journal of Islamic Studies, 55(2), 391426. https://doi.org/10.14421/ajis.2017.552.391-426

Abdurrahman, N. H. (2016). Character Education in Islamic Boarding School- Based Sma Amanah. Jurnal Pendidikan Islam, 2(2), 287-305. https://doi.org/10.15575/jpi.v2i2.791 
Agung, A. (2018). Konsep Pendidikan Karakter Islami; Kajian Epistemologis. Al-Tarbawi AlHaditsah : Jurnal Pendidikan Islam, 3(2). https://doi.org/10.24235/tarbawi.v3i2.3315

Amri, M., Saharuddin, S., \& Ahmad, L. O. I. (2019). The Implementation of Islamic Education: The Process of Instilling Akhlakul Karimah (Noble Characters) for Madrasah Tsanawiyah Students. Tadris: Jurnal Keguruan Dan Ilmu Tarbiyah, 4(1), 117-125. https://doi.org/10.24042/tadris.v4i1.4070

Ariyanti, N. S., Supriyanto, A., \& Timan, A. (2019). Kontribusi Kepala Sekolah Berdasarkan Ketidaksesuain Kualifikasi Guru Untuk Meningkatkan Kualitas Sekolah. Nidhomul Haq: Jurnal Manajemen Pendidikan Islam, 4(2), 157-168. https://doi.org/10.31538/ndh.v4i2.314

Asmendri. (2014). The Roles of School Principal in the Implementation of Character Education at Boarding School. Al-Ta Lim Journal, 21(2), 104-111. https://doi.org/10.15548/jt.v21i2.87

Baharun, H., \& Ummah, R. (2018). Strengthening Students' Character in Akhlaq Subject Through Problem Based Learning Model. Tadris: Jurnal Keguruan Dan Ilmu Tarbiyah, 3(1), 21-30. https://doi.org/10.24042/tadris.v3i1.2205

Berkowitz, M. W., \& Bier, M. C. (2016). Research-Based Character Education. The Annals of the American Academy of Political and Social Science. https://doi.org/10.1177/0002716203260082

Brooks, M. C., \& Mutohar, A. (2018). Islamic school leadership: A conceptual framework. Journal of Educational Administration and History, 50(2), 54-68. https://doi.org/10.1080/00220620.2018.1426558

Brooks, M. C., \& Sungtong, E. (2016). 'We still have bombings': School principals and insurgent violence in Southern Thailand. International Journal of Leadership in Education, 19(5), 505533. https://doi.org/10.1080/13603124.2015.1059489

Creswell, J. W. (2012). Educational research: Planning, conducting, and evaluating quantitative and qualitative research (4th ed). Pearson.

Fatoni, M. (2017). Peran Kepala Madrasah Dalam Meningkatkan Mutu Guru Di Mts Nurul Falah Talok Kresek Kabupaten Tangerang. Tarbawi: Jurnal Keilmuan Manajemen Pendidikan, 3(02), 168-182. https://doi.org/10.32678/tarbawi.v3i02.1787

Fauzi, A. (2017). Kepemimpinan Kepala Madrasah Dalam Mengembangkan Lembaga Pendidikan Islam. Nidhomul Haq: Jurnal Manajemen Pendidikan Islam, 2(2), 42-53. http://ejournal.ikhac.ac.id/index.php/nidhomulhaq/article/view/31

Fitriani, M. I. (2017). Systemic and Systematic Steps of Leadership on Transforming Symbolic into Substantive Characteristic of Madrasah. Jurnal Pendidikan Islam, 3(1), 1-16. https://doi.org/10.15575/jpi.v3i1.1203

Fitriani, M. I., \& Hakim, M. V. F. (2021). Principal Leadership Patterns in Collaborating With School Committee. Nidhomul Haq: Jurnal Manajemen Pendidikan Islam, 6(1), 194-205. https://doi.org/10.31538/ndh.v6i1.1384

Ilmi, M. U., Setiawan, F., Hikmah, M. N., Kharisma, A., Feryawan, D., \& Hanafie, A. A. (2021). The Basic Concepts of Evaluation and Its Implementation in IRE Lessons in The Pandemic Era. Tafkir: Interdisciplinary Journal of Islamic Education, 2(2), 175-190. https://doi.org/10.31538/tijie.v2i2.50

Kosim, M., Kustati, M., Sabri, A., \& Mustaqim, M. (2019). Strengthening Students' Character through Tahfidz Quran in Islamic Education Curriculum. Jurnal Pendidikan Islam, 8(1), 6994. https://doi.org/10.14421/jpi.2019.81.69-94

Lexy J, M. (2011). Metodologi penelitian Kualitatif (29th ed.). Rosdakarya. 
Miles, M. B., Huberman, A. M., \& Saldaña, J. (2014). Qualitative data analysis: A methods sourcebook (Third edition). SAGE Publications, Inc.

Muhaimin. (2012). Pengembangan Kurikulum Pendidikan Agama Islam (Cet. 5). Raja Grafindo Persada.

Muslimin, T. A., \& Kartiko, A. (2020). Pengaruh Sarana dan Prasarana Terhadap Mutu Pendidikan di Madrasah Bertaraf Internasional Nurul Ummah Pacet Mojokerto. Munaddhomah: Jurnal Manajemen Pendidikan Islam, 1(2), 75-87. https://pasca.jurnalikhac.ac.id/index.php/munaddhomah/article/view/30

Nurulloh, A., Aprilianto, A., Sirojuddin, A., \& Maarif, M. A. (2020). THE ROLE OF THE HEAD OF MADRASAH'S POLICY IN IMPROVING TEACHER PROFESSIONALISM. Nidhomul Haq : Jurnal Manajemen Pendidikan Islam, 5(3), 334-346. https://doi.org/10.31538/ndh.v5i3.963

Prayoga, A., Noorfaizah, R. S., Suryana, Y., \& Sulhan, M. (2019). Manajemen Pembelajaran Tahfidzul Quran Berbasis Metode Yaddain Di Mi Plus Darul Hufadz Sumedang. Nidhomul Haq: Jurnal Manajemen Pendidikan Islam, 4(2), 140-156. https://doi.org/10.31538/ndh.v4i2.326

Sobri, R. (2019). Politik Dan Kebijakan: Pendidikan Agama Dan Keagamaan Di Indonesia (analisis Kebijakan Pp No 55 Tahun 2007). Edukasi Islami: Jurnal Pendidikan Islam, 8(01), 109-124. https://doi.org/10.30868/ei.v8i01.322

Tafsir, A. (2012). Ilmu pendidikan Islami (Cet. 1). Remaja Rosdakarya.

Wahjosumidjo. (1999). Kepemimpinan kepala sekolah: Tinjauan teoritik dan permasalahannya. Rajagrafindo Persada (Rajawali Pers). 